\title{
1 Title: COVID-19 and frontline health workers in West Africa: a scoping review
}

3 Kingsley K. A. Pereko ${ }^{1 \pi}$, Edward Kwabena Ameyaw ${ }^{2 \pi}$, Shaibu Bukari ${ }^{3 \&}$, Victoria Acquaye ${ }^{4 \&}$,

$4 \quad$ Alfred Dickson Dai-Kosi ${ }^{5 \&}$

5

$6 \quad{ }^{1}$ Department of Community Medicine, School of Medical Sciences, University of Cape

7 Coast, Cape Coast, Ghana

$8{ }^{2}$ School of Public Health, Faculty of Health, University of Technology Sydney, Australia

$9 \quad{ }^{3}$ University of Cape Coast, Cape Coast, Ghana

$10{ }^{4}$ Psychological Medicine and Mental Health, School of Medical Sciences, University of Cape

11 Coast, Cape Coast, Ghana

$12{ }^{5}$ Department of Community Dentistry, School of Medicine and Dentistry, University of

13 Ghana, Legon

*Corresponding author

16 Email addresses:

KAA: *kpereko@ucc.edu.gh

EKA: edmeyaw19@gmail.com

SB: sbukari@ucc.edu.gh

VA: v.acquaye@uccsms.edu.gh

ADD-K: daikosi@yahoo.com

23 IT These authors contributed equally to this work.

$24 \quad{ }^{\&}$ These authors also contributed equally to this work. 


\section{Abstract}

\section{Introduction}

27 The novel Coronavirus 2019 (COVID-19) has become a severe global health threat since its

28 emergence. Overcoming the virus is partly dependent on the holistic wellbeing of frontline

29 health workers. Implications of COVID-19 on frontline health workers in West Africa could

30 be substantial given the limited resources and logistics. This scoping review maps available

31 literature on the impact of COVID-19 on frontline health workers in West Africa.

\section{Materials and methods}

33 Literature on the impact of COVID-19 on frontline health workers in West Africa were 34 searched in six databases namely Cochrane Library, PubMed, EMBASE, Google Scholar, 35 Africa Journals Online (AJOL) and CINAHL. Further search was done across websites of the 36 ministries of health of West African countries and notable organisations. We conducted a 37 narrative synthesis of the findings taking cognisance of the overarching purpose of the study 38 and the research question.

\section{Results}

40 Of the 67 studies identified, 19 were included in the final synthesis. Three main themes 41 emerged and these are impact of COVID-19 on frontline health workers, drivers of 42 susceptibility to COVID-19 and government/donor support. A greater number of the studies 43 originated from Nigeria. Each study reported at least one impact of COVID-19 on frontline 44 health workers in West Africa. The impacts included death, fear, unwillingness to attend to 45 COVID-19 patients and stigmatisation. Some health workers were not adhering to the safety 
46 protocols coupled with periodic shortage of personal protective equipment (PPE) and thereby

47 had an increased susceptibility.

\section{Conclusion}

49 Being the first scoping review on the impact of COVID-19 on frontline health workers in

50 West Africa, the study has illustrated the urgent need for West African governments to enact

51 laws/rules that would compel all frontline health workers to adhere to all the COVID-19

52 protocols at the workplace. To end intermittent shortage or issue of inadequate PPEs, 53 governments ought to liaise with local industries by empowering them, providing financial 54 support and creating a conducive atmosphere for them to produce cost effective PPEs using 55 available local resources.

56 Scoping review registration: DOI 10.17605/OSF.IO/B9NXZ (Open Science 57 Framework)

59 Key words: COVID-19, frontline, health workers, healthcare, global health, West Africa 


\section{Introduction}

68 The novel Coronavirus 2019 (COVID-19) has become a severe global health threat since its

69 emergence [1]. As of 5:15pm CEST, 1 October 2020, there were 33,842,281 cases of

70 COVID-19 with 1,010,634 deaths globally [2]. The pandemic has affected both low and

71 middle-income countries as well as high income countries. The role of frontline healthcare

72 providers is therefore indispensable in the combat against COVID-19. These health workers

73 are expected to have a close exposure to COVID-19 infected persons at varying stages of the

74 infection thereby increasing their susceptibility and tendency of further spread [3]. In spite of

75 the fact that COVID-19 has impacted the global community, the virulence level and impact

76 vary across environmental, demographic, socio-economic and demographic spheres [4].

77 Admittedly, healthcare providers have been impacted by the COVID-19 in high income

78 countries such as the UK and USA [3]. However, the impact for frontline health workers in

79 low and middle income countries such as those in West Africa may be substantial owing to a

80 number of factors. For instance, in addition to the fact that health indices in West African

81 countries are the lowest in the world, the pandemic can easily overwhelm the ailing health

82 systems across West Africa, which are operated by inadequate health personnel [5]. In

83 addition, implications of COVID-19 on frontline health workers in West Africa could be

84 substantial given the limited resources and logistics [6]. All countries in West Africa are in

85 either low or middle income category with little budget allocation to the health sector, thus

86 ranging between $0.6 \%$ and $3.4 \%$ [5]. The sparse distribution and rural nature of some

87 locations could pose difficulty in sending an infected health worker from a rural setting to a

88 tertiary or secondary level health facilities which are predominantly in urban locations [7].

89 Consequently, the ability of countries in the sub-region to finance and implement the 
requisite measures needed to protect frontline health workers and boost the health systems to rise to the pandemic may be compromised.

92 Overcoming the novel COVID-19 is partly dependent on the holistic wellbeing of frontline

93 health workers [7]. Even though protection of frontline health workers against COVID-19 is a

94 priority global concern $[8,9]$, no scoping review have been executed to collate the magnitude

95 of impact on frontline health workers, the specific factors that increase susceptibility and measures instituted to protect frontline health workers from the impacts of the virus in West Africa. COVID-19 has been confirmed in all sixteen (16) West African countries [10]. By September $22^{\text {nd }} 2020$, a total of 172,594 cases and 2,580 deaths had been recorded in the subregion [11].

The WHO reports that COVID-19 infections among frontline health workers usually occur at the work place [12]. This underscores the need to explore the situation in West Africa to unravel the documeted impact of the virus on frontline health workers. Previous studies on COVID-19 in West Africa are predominantly reviews focusing on specific countries [13-17].

This is therefore the first scoping review to collate evidence on the impact of COVID-19 on frontline health workers in West Africa guided by the question: "How has COVID-19 impacted frontline healthcare providers in West Africa?" Outcome of the study would not only inform governments and policy makers on the specific socio-culturally sensitive policies required to safeguard the wellbeing of the limited frontline health workers but would as well prompt frontline health workers on what they could do at the personal level to mitigate their susceptibility to the virus whilst taking care of COVID-19 and other patients.

\section{Materials and methods}

112 We conducted a scoping review between July and October 2020 with respect to the 113 guidelines of the Joanna Briggs Institute's Preferred Reporting Items for Systematic Reviews 
medRxiv preprint doi: https://doi.org/10.1101/2020.10.15.20213249; this version posted October 16, 2020. The copyright holder for this preprint (which was not certified by peer review) is the author/funder, who has granted medRxiv a license to display the preprint in perpetuity.

It is made available under a CC-BY-NC-ND 4.0 International license .

and Meta-Analyses Extension for Scoping Reviews (PRISMA-ScR) checklist [18]. This study was guided by a protocol registered with the Open Science Framework (DOI 10.17605/OSF.IO/B9NXZ).

\section{Population of interest}

The review focused on frontline health workers in West Africa. Frontline health worker included any category of healthcare provider who has been providing healthcare and have been directly interacting with patients from 2019 to August 2020.

\section{Eligibility criteria and study selection}

Citations of all published articles were first exported to EndNote and subsequently to the Covidence online systematic review platform. Three key steps were followed to screen the studies; (a) deduplication, (b) title and abstract screening and, (c) full text screening. In the case of the grey literature, selection for inclusion was strictly based on the assessment outcome as well as inclusion and exclusion criteria of the study. Included studies satisfied the following: (i) conducted in West Africa, (ii) reports about frontline health workers, (iii) focuses on any impact of COVID-19, (iv) employed experimental/quasi-experimental, observational, quantitative, qualitative, mixed methods, (v) reports/editorials/commentaries, (vi) in English, French or Spanish (vii) and published between December 2019 and August 2020. Out of the total studies, 19 were included in the final synthesis (see Figure 1).

\section{Sources of data and search strategy}

We conducted an electronic search for both peer-reviewed articles and grey literature. Six databases were searched for published articles: Cochrane Library, PubMed, EMBASE, Google Scholar, Africa Journals Online (AJOL) and CINAHL. We searched for grey literature (e.g. reports, press periodic briefings) from the websites of ministries of health of 
137 all the sixteen West African countries and websites of reputable agencies that report on

138 COVID-19 situation in West Africa such as the Africa Centres for Disease Control and

139 Prevention (Africa CDC), and WHO Regional Office for Africa. Our search followed four

140 cardinal steps: (1) use of search terms for articles in the six aforesaid databases; (2) search for

141 grey literature from websites of key organisations and ministries of health of each West

142 African country; (3) manual search for commentaries/editorials/opinions and; (4) manual

143 search of reference lists of included article. A complete search strategy and key words used

144 for PubMed have been provided (S1).

145
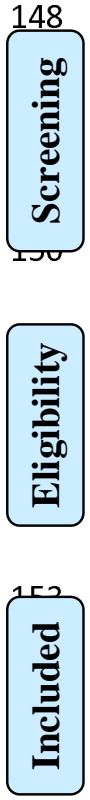

155

$$
\begin{aligned}
& \text { Records identified through } \\
& \text { database searching } \\
& (\mathrm{n}=31)
\end{aligned}
$$

Additional records identified through other sources and reference check

$$
(n=36)
$$

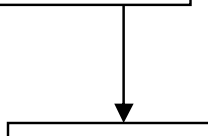

Irrelevant records

\begin{tabular}{|c|c|}
\hline$\downarrow$ & $\begin{array}{l}\text { Full-text excluded } \\
\qquad(\mathrm{n}=8)\end{array}$ \\
\hline $\begin{array}{l}\text { Full-text articles } \\
\text { assessed for eligibility } \\
\qquad(\mathrm{n}=27)\end{array}$ & $\begin{array}{l}\text { Wrong study design } \\
(\mathrm{n}=3)\end{array}$ \\
\hline$\downarrow$ & $\begin{array}{l}\text { Wrong population } \\
(\mathrm{n}=4)\end{array}$ \\
\hline $\begin{array}{l}\text { Studies included in } \\
\text { qualitative synthesis }\end{array}$ & $\begin{array}{l}\text { Wrong reporting } \\
\text { period }(n=1)\end{array}$ \\
\hline
\end{tabular}

$$
(n=34)
$$

deduplication

$(\mathrm{n}=61)$

$$
(\mathrm{n}=19)
$$




\section{Quality assessment}

160 The quality assessment was conducted independently by one author (EKA) and verified by 161 another author (KAP). This was done with the McMaster Critical review [19]. The 162 Authority, Accuracy, Coverage, Objectivity, Date, and Significance (AACODS) Checklist 163 was used to assess the quality of the non-peer reviewed studies [20].

165 Data charting

166 We developed a data charting form and this was used to extract important data required to address the overarching review question. The form constituted the following components: (a) author(s) and year of publication, (b) country/scope of study, (c) title, (d) study type, (e) study design, (f) theme and; (g) key findings.

\section{Synthesis and reporting of findings}

172 We carried out a thematic analysis of the findings from the included studies. Thematic analysis is "a method for identifying, analyzing and reporting patterns within data." [21]. Three principal themes emerged and the findings were categorised according to these themes. Subsequently, we interpreted and conducted a narrative synthesis of the findings taking cognisance of the overarching purpose of the study and the research question. 


\section{Results}

\section{Characteristics of included studies/reports}

182 A total of 19 studies were included in the synthesis and these are summarised in Table 1.

183 Most of the studies were reviews $(n=7)$ and there was only one original research article which

184 used a quantitative approach [22]. All studies were conducted in 2020, in English and most 185 were from Nigeria $(\mathrm{n}=8)$.

186

187 Table 1. Characteristics of included studies/reports

\begin{tabular}{|l|l|l|l|l|l|}
\hline$\#$ & Author (year) & Country/Scope & Title & Study type & Study design \\
\hline 1. & Ogolodom et & Nigeria & Knowledge, Attitudes & Original & Quantitative \\
& al. (2020) & & $\begin{array}{l}\text { Workers towards the } \\
\text { Corona Virus Disease } \\
\text { (COVID-19) Pandemic }\end{array}$ & & \\
\hline 2. & UNICEF & Guinea-Bissau & GUINEA-BISSAU: & Report & n/a \\
& (2020) & & COVID-19 Situation & & \\
& & & Report - \#17 & n/a \\
\hline 3. & Darboe M.K. & Gambia & Gambia's health system & Personal & \\
\hline
\end{tabular}




\begin{tabular}{|c|c|c|c|c|c|}
\hline & & & pandemic & & \\
\hline 4. & $\begin{array}{l}\text { Shaban A.R.A. } \\
(2020)\end{array}$ & Ghana & $\begin{array}{l}\text { Ghana coronavirus: } \\
\text { 29,672 cases; } 100 \text {-bed } \\
\text { specialist hospital ready }\end{array}$ & News article & $\mathrm{n} / \mathrm{a}$ \\
\hline 5. & $\begin{array}{l}\text { Nakri E. } \\
(2020)\end{array}$ & Ghana & $\begin{array}{l}\text { Striving to keep health } \\
\text { worker infections at bay }\end{array}$ & $\begin{array}{l}\text { Personal } \\
\text { reflection }\end{array}$ & $\mathrm{n} / \mathrm{a}$ \\
\hline 6. & $\begin{array}{l}\text { Quakyi N.K. } \\
(2020)\end{array}$ & Ghana & $\begin{array}{l}\text { Ghana's much praised } \\
\text { COVID-19 strategy has } \\
\text { gone awry. Here is why }\end{array}$ & Commentary & $\mathrm{n} / \mathrm{a}$ \\
\hline 7. & $\begin{array}{l}\text { Agence de } \\
\text { Presse } \\
\text { Africaine } \\
\text { (APA) (2020) }\end{array}$ & Ghana & $\begin{array}{l}\text { Ghana: Press highlights } \\
\text { recovery of } 1870 \text { health } \\
\text { workers from Covid-19, } \\
\text { others }\end{array}$ & Review & $\mathrm{n} / \mathrm{a}$ \\
\hline 8. & $\begin{array}{l}\text { CGTN Africa } \\
(2020)\end{array}$ & Guinea-Bissau & $\begin{array}{l}\text { Nearly } 10 \% \text { of Guinea- } \\
\text { Bissau health workers } \\
\text { infected with COVID- } \\
19\end{array}$ & Review & $\mathrm{n} / \mathrm{a}$ \\
\hline 9. & $\begin{array}{l}\text { Brown W. } \\
(2020)\end{array}$ & Guinea-Bissau & $\begin{array}{l}\text { Hospitals in tiny } \\
\text { Guinea-Bissau } \\
\text { 'overwhelmed' by the } \\
\text { pandemic }\end{array}$ & Review & $\mathrm{n} / \mathrm{a}$ \\
\hline 10 & WHO (2020a) & Africa & $\begin{array}{l}\text { COVID-19 WHO } \\
\text { African Region External } \\
\text { Situation Report } 15\end{array}$ & Report & $\mathrm{n} / \mathrm{a}$ \\
\hline 11. & Karmo H. & Liberia & Liberia: Minister of & News article & $\mathrm{n} / \mathrm{a}$ \\
\hline
\end{tabular}




\begin{tabular}{|c|c|c|c|c|c|}
\hline & (2020) & & $\begin{array}{l}\text { Health Attributes } \\
\text { COVID-19 Infections } \\
\text { among Health Workers } \\
\text { to 'State of Denial' of } \\
\text { Nurses }\end{array}$ & & \\
\hline 12. & Tih F. (2020) & Nigeria & $\begin{array}{l}\text { Nigeria: } 800 \text { health } \\
\text { workers infected with } \\
\text { COVID-19 }\end{array}$ & $\begin{array}{l}\text { Personal } \\
\text { reflection }\end{array}$ & $\mathrm{n} / \mathrm{a}$ \\
\hline 13. & $\begin{array}{l}\text { Okunola } \\
\text { A. }(2020)\end{array}$ & Nigeria & $\begin{array}{l}5 \text { Challenges Facing } \\
\text { Health Care Workers in } \\
\text { Nigeria as They Tackle } \\
\text { COVID-19 }\end{array}$ & Review & $\mathrm{n} / \mathrm{a}$ \\
\hline 14. & $\begin{array}{l}\text { Clottey P. \& } \\
\text { Dauda M. } \\
\text { (2020) }\end{array}$ & Nigeria & $\begin{array}{l}\text { Striking Doctors in } \\
\text { Nigeria Demand } \\
\text { COVID-19 PPE, Hazard } \\
\text { Pay }\end{array}$ & Review & $\mathrm{n} / \mathrm{a}$ \\
\hline 15. & $\begin{array}{l}\text { Nwosu-Igbo N } \\
(2020)\end{array}$ & Nigeria & $\begin{array}{l}\text { In the frontline of } \\
\text { Nigeria's struggle with } \\
\text { COVID-19 }\end{array}$ & Review & $\mathrm{n} / \mathrm{a}$ \\
\hline 16. & $\begin{array}{l}\text { Onyeji E. } \\
(2020)\end{array}$ & Nigeria & $\begin{array}{l}\text { COVID-19: As more } \\
\text { health workers get } \\
\text { infected, JOHESU } \\
\text { distributes PPEs }\end{array}$ & News article & $\mathrm{n} / \mathrm{a}$ \\
\hline 17. & $\begin{array}{l}\text { Amnesty } \\
\text { International }\end{array}$ & Nigeria & $\begin{array}{l}\text { Nigeria: Authorities } \\
\text { must protect health }\end{array}$ & Review & $\mathrm{n} / \mathrm{a}$ \\
\hline
\end{tabular}




\begin{tabular}{|l|l|l|l|l|l|}
\hline & (2020) & & $\begin{array}{l}\text { workers on the frontline } \\
\text { of COVID-19 response }\end{array}$ & & \\
\hline 18. & Mwai P. \& & Nigeria & Coronavirus: How & News article & $\mathrm{n} / \mathrm{a}$ \\
\hline 19. & Giles C. & & vulnerable are health & & \\
& Workers in Nigeria? & COVID-19 WHO & Report & $\mathrm{n} / \mathrm{a}$ \\
\hline
\end{tabular}

190 Three principal themes emerged from the included studies: (a) impact of COVID-19 on

191 frontline health workers; (b) drivers of susceptibility to COVID-19 and; (c)

192 government/donor support. All the records associated with each theme and sub-theme are 193 summarised in Table 2.

\section{Theme 1: impact of COVID-19 on frontline health workers}

195 Almost all included studies reported at least one impact of COVID-19 on frontline health 196 workers. The dominant impact was COVID-19 infection among frontline health workers such 197 as doctors and nurses as reported by fourteen studies [13, 14, 16, 17, 23-32]. Some health 198 care providers expressed fear of being at risk of contracting COVID-19 and subsequent death $199[17,22,28,33]$ as well as expression of worry and sadness [34]. COVID-19 had also reduced 200 the passion or willingness to work in Nigeria [22], and also brought about stigmatisation and 201 separation from families [29]. 
203 Three dominant factors were noted to increase frontline health workers' susceptibility to

204 COVID-19 in West Africa. The commonly reported was inadequate infrastructure/equipment 205 predominantly from Nigeria [15, 16, 28, 33, 35], Ghana [17] and Guinea-Bissau [13]. In the 206 case of Ghana [34] and Liberia [26], non-adherence to the COVID-19 safety protocols among 207 frontline health workers was reported whilst insecure work environment [22] was recounted 208 as factor that enhances susceptibility of frontline health workers to COVID-19 in Nigeria $209[22]$.

\section{Theme 3: Government/Donor support}

211 To alleviate the impact of COVID-19 on frontline health workers, governments have adopted 212 varied interventions and strategies. A number of non-governmental and international 213 organisations have also supported. For instance, the United Nations International Children's 214 Emergency Fund (UNICEF) appeared to have assisted in diverse ways. Specific approaches 215 for combating the COVID-19 among frontline healthcare providers include training as 216 evidenced in Guinea-Bissau and Nigeria [23, 35] as well as acquisition and distribution of 217 personal protective and other essential equipment as reported from The Gambia [14], and 218 Nigeria [16, 35]. The support have also manifested in physical infrastructure [24] and 219 provision of social services (e.g. encouraging preventive actions in communities through risk 220 communications) [35] in Ghana and Nigeria respectively.

\section{Table 2: Themes and sub-themes from included studies}

\begin{tabular}{|l|l|l|}
\hline Theme & \multicolumn{1}{|c|}{ Key findings } & Included studies \\
\hline Impact of COVID-19 & Infected frontline health & {$[13,14,16,17,23-32]$} \\
on frontline health & workers $(\mathrm{n}=14)$ & \\
workers & & \\
\hline
\end{tabular}




\begin{tabular}{|c|c|c|}
\hline & $\begin{array}{l}\text { Fear of being at risk } \\
(n=3)\end{array}$ & {$[17,22,28]$} \\
\hline & $\begin{array}{l}\text { Reduced willingness to } \\
\text { go to work }(n=1)\end{array}$ & {$[22]$} \\
\hline & Worry $(\mathrm{n}=1)$ & [34] \\
\hline & Sadness $(\mathrm{n}=1)$ & {$[34]$} \\
\hline & Death $(n=2)$ & {$[28,33]$} \\
\hline & Stigmatization $(\mathrm{n}=1)$ & [29] \\
\hline & Mental health $(\mathrm{n}=1)$ & [29] \\
\hline & $\begin{array}{l}\text { Separation from } \\
\text { families }(n=1)\end{array}$ & [29] \\
\hline \multicolumn{3}{|l|}{ Drivers of susceptibility } \\
\hline & $\begin{array}{l}\text { Insecure workplace } \\
\text { environment }(n=1)\end{array}$ & {$[22]$} \\
\hline & $\begin{array}{l}\text { Non-adherence to safety } \\
\text { protocols/carelessness } \\
(n=2)\end{array}$ & {$[26,34]$} \\
\hline & $\begin{array}{l}\text { Inadequate } \\
\text { infrastructure/equipment } \\
(\mathrm{n}=7)\end{array}$ & {$[13,15-17,28,33,35]$} \\
\hline \multirow[t]{2}{*}{$\begin{array}{l}\text { Government/Donor } \\
\text { support (e.g. UNICEF) }\end{array}$} & Training $(\mathrm{n}=2)$ & {$[23,35]$} \\
\hline & Equipment acquisition & {$[14,16,35]$} \\
\hline
\end{tabular}




\begin{tabular}{|l|l|l|}
\hline & /distribution $(\mathrm{n}=3)$ & \\
\hline & $\begin{array}{l}\text { Physical infrastructure } \\
(\mathrm{n}=1)\end{array}$ & {$[24]$} \\
\hline & Social services $(\mathrm{n}=1)$ & {$[35]$} \\
\hline
\end{tabular}

\section{Discussion}

224 This review is the first to synthesise evidence on the impact of COVID-19 on frontline health

225 workers in West Africa. The review has illustrated the peculiar implications of COVID-19 on

226 frontline health workers in West Africa, factors that increase their susceptibility and ongoing

227 support/commitment by governments and donor organisations.

228 A key theme from the review is that COVID-19 has affected and continues to affect frontline

229 health workers in diverse ways with infection among frontline health workers emerging as

230 the dominant impact. Others were death, fear of being at risk, worry, attenuated preparedness

231 to work, stigmatisation and insecure workplace. This indicates that West Africa contributes to

232 the globally estimated 30,000 deaths among frontline health workers [36]. Due to these

233 implications, some health workers are reluctant to attend to COVID-19 patients even if

234 adequately compensated [22]. Similar reports have emerged from other countries outside

235 West Africa such as Mexico, Saudi Arabia and Pakistan where death, worry and mental

236 health issues were noted among frontline health workers [37-39]. The findings indicate the

237 need for extra care and support for West African based frontline health workers especially

238 during pandemics because the overwhelmed health systems further present challenging times

239 for health workers [40]. To this end, putting in place sustainable insurance policy [22],

240 ensuring safe, decent work conditions and intermittent psychological services for frontline

241 health workers may be required to mitigate these implications in West Africa [40]. These can 
medRxiv preprint doi: https://doi.org/10.1101/2020.10.15.20213249; this version posted October 16, 2020. The copyright holder for this preprint (which was not certified by peer review) is the author/funder, who has granted medRxiv a license to display the preprint in perpetuity.

It is made available under a CC-BY-NC-ND 4.0 International license.

242 be achieved through inter-sectoral collaboration between governments, employers and 243 workers' organisations. More importantly, stakeholders' ability to contexualise protective 244 measures in line with local resources and inter-country nuances might be prudent.

245 The review identified three factors that incline frontline health workers to COVID-19 in West

246 Africa; insecure workplace environment, non-adherence to COVID-19 safety protocols or 247 carelessness and inadequate infrastructure and equipment including Personal Protective 248 Equipment (PPE). These reflect both systemic gaps and negligence on the part of frontline 249 health workers. In as much as West African governments and their partners are obliged to 250 ensure safety and holistic wellbeing of frontline health workers amidst the COVID-19, the 251 frontline health workers also have an essential role to play in order to ameliorate the situation.

252 Some level of discipline is required by the frontline health workers to ensure their own safety 253 because non-use of PPEs or non-adherence of the COVID-19 protocols is as perilous 254 government's refusal to purchase and distribute such lifesaving resources or equipment.

255 More workshops on COVID-19 protocols, constant reminders (e.g. through text messaging, 256 audio-visuals) and sanctioning of frontline health workers who ignore the protocols may help 257 to ensure that the all frontline health workers in West Africa are committed to ensuring their 258 own safety. Further, frontline health workers who are sensitive to the COVID-19 protocols 259 and those who fully observe the protocols may be incentivised to motivate others to do same. 260 Government and partner organisations, however, may have to intervene to ensure safe 261 workplace for the frontline health workers by expanding infrastructure and ensuring 262 consistent supply of PPEs. Regular training of health workers in emergency preparedness can 263 make them conscious and responsive the pandemic and subsequent disease outbreaks.

264 The study revealed that the support offered to frontline health workers by West African 265 governments and donor organisations manifest in training, acquisition and distribution of 
equipment, physical infrastructure and social services. These illustrate that governments of various West African countries and some donor partners have instituted some measures with respect to infrastructure and equipment with the aim of boosting the health systems to overcome the novel COVID-19. In Gambia, for instance, the government has expended $\$ 12$ million on equipment to support the country's health by acquiring ventilators, ambulances and PPEs since March 2020 to support the overwhelmed health system and expedite the combat against COVID-19 [14]. A number of West African countries such as Ghana and

273 Nigeria have done same through the assistance of partner organisations such as the WHO [41,

42]. West African countries can also establish health emergency funds to cushion the health systems during disease outbreaks.

However, our evidence support previous findings on the inadequacy and intermittent shortage of essential PPEs among frontline health workers [43, 44]. Most of these PPEs are imported [45] and could possibly account for the intermittent shortages. It is therefore imperative for

West African countries to ulitise local resources to develop domestic PPEs whenever possible

in order not to be over reliant on international trade. This is essentially critical considering that the pandemic compelled most countries to close their borders, a situation that do not permit international transfer of PPEs.

\section{Strengths and limitations}

284 Most of the included studies were not peer-reviewed. This is due to the recency of COVID-19 and its late entry into West Africa compared to other sub-regions. The review focused on only frontline health workers and hence could not account for the impact of COVID-19 on other category of health workers within West Africa.

\section{Conclusion}


289 Being the first scoping review on the impact of COVID-19 on frontline health workers in

290 West Africa, the review has highlighted the specific impacts, as well as essential systemic

291 and health personnel gaps reinforcing the impact. The review has also revealed ongoing

292 support and commitment by governments and partner organisations. There is an urgent need

293 for West African governments to enact laws/rules that would compel all frontline health

294 workers to adhere to all the COVID-19 protocols at the workplace. Effective supervision may

295 be essential for achieving full implementation of such laws/rules. To end intermittent

296 shortage or issue of inadequate PPEs, governments ought to liaise with local industries by

297 empowering them, providing financial support and creating a conducive atmosphere for them

298 to produce cost effective PPEs using available local resources. More empirical studies are

299 required to better understand the country specific and contextual factors associated with the

300 impact of COVID-19 on frontline health workers across the sixteen West African countries.

302 Acknowledgements

303 None

304 Funding

305 No funds were received for this review. 
medRxiv preprint doi: https://doi.org/10.1101/2020.10.15.20213249; this version posted October 16, 2020. The copyright holder for this preprint (which was not certified by peer review) is the author/funder, who has granted medRxiv a license to display the preprint in perpetuity.

It is made available under a CC-BY-NC-ND 4.0 International license .

310 1. Anderson RM, Heesterbeek H, Klinkenberg D, Hollingsworth TD. How will country-

311 based mitigation measures influence the course of the COVID-19 epidemic? The Lancet.

$312 \quad 2020 ; 395(10228): 931-4$.

$313 \quad 2 . \quad$ WHO. WHO Coronavirus Disease (COVID-19) Dashboard Geneva: WHO; 2020

314 [Available from:

315 https://covid19. who.int/?gclid=CjwKCAjw8MD7BRArEiwAGZsrBQ2yYd2-

316 6VgsiUW8nfsXQc6r50bXGpV-fwjwYnwxyXmfK99ZCJA0bhoCkOwQAvD_BwE.

317 3. Nguyen LH, Drew DA, Graham MS, Joshi AD, Guo C-G, Ma W, et al. Risk of

318 COVID-19 among front-line health-care workers and the general community: a prospective

319 cohort study. The Lancet Public Health. 2020;5(9):e475-e83.

320 4. Qu G, Li X, Hu L, Jiang G. An imperative need for research on the role of

321 environmental factors in transmission of novel coronavirus (COVID-19). ACS Publications;

3222020

323 5. Nwakanma C, Nnamdi KC. Health care Financing and Health Profile in West African 324 Countries. 2013.

325 6. Ren L-L, Wang Y-M, Wu Z-Q, Xiang Z-C, Guo L, Xu T, et al. Identification of a 326 novel coronavirus causing severe pneumonia in human: a descriptive study. Chinese Medical 327 Journal. 2020

328 7. Chersich MF, Gray G, Fairlie L, Eichbaum Q, Mayhew S, Allwood B, et al. COVID32919 in Africa: care and protection for frontline healthcare workers. Globalization Health Sci J. $330 \quad 2020 ; 16: 1-6$

331 8. CDC. COVID-19 Response Team. Characteristics of health care personnel with 332 COVID-19: United States. MMWR Morb Mortal Wkly Rep. 2020;69:477-81.

333 9. The Lancet. COVID-19: protecting health-care workers. Lancet 2020;395: 922. 
medRxiv preprint doi: https://doi.org/10.1101/2020.10.15.20213249; this version posted October 16, 2020. The copyright holder for this preprint (which was not certified by peer review) is the author/funder, who has granted medRxiv a license to display the preprint in perpetuity.

It is made available under a CC-BY-NC-ND 4.0 International license .

334 10. Nachega J, Seydi M, Zumla A. The Late Arrival of Coronavirus Disease 2019

335 (COVID-19) in Africa: Mitigating Pan-continental Spread. Clinical Infectious Diseases.

$336 \quad 2020 ; 71(15): 875-8$.

337 11. Africa Centres for Disease Control (CDC). Outbreak Brief \#36: Coronavirus Disease

3382019 (COVID-19) Pandemic 2020 [Available from: https://africacdc.org/download/outbreak-

339 brief-36-covid-19-pandemic-22-september-2020/.

340 12. WHO. Coronavirus Disease (COVID-19) Outbreak 2020 [cited 202002 August].

341 Available from: https://www.who.int/emergencies/diseases/novel-coronavirus-2019

342 13. CGTN Africa. Nearly $10 \%$ of Guinea-Bissau health workers infected with COVID-19

3432020 [cited 2020 August 23]. Available from: https://africa.cgtn.com/2020/06/17/nearly-10-

344 of-guinea-bissau-health-workers-infected-with-covid-19/.

345 14. Darboe MK. Gambia's health system near collapse amid pandemic: Anadolu Agency;

3462020 [cited 2020 August 20]. Available from: https://www.aa.com.tr/en/africa/gambia-s-

347 health-system-near-collapse-amid-pandemic/1937191.

348 15. Okunola A. 5 Challenges Facing Health Care Workers in Nigeria as They Tackle

349 COVID-19 2020 [cited 2020 August 18]. Available from:

350 https://www.globalcitizen.org/en/content/challenges-for-health-care-workers-nigeria-covid/.

351 16. Onyeji E. COVID-19: As more health workers get infected, JOHESU distributes

352 PPEs 2020 [cited 2020 August 25]. Available from:

353 https://www.premiumtimesng.com/health/health-interviews/402242-covid-19-as-more-

354 health-workers-get-infected-johesu-distributes-ppes.html.

355 17. Quakyi NK. Ghana's much praised COVID-19 strategy has gone awry. Here is why.

356 The Conversation. 2020.

357 18. Peters MDJ, Godfrey C, McInerney P, Baldini SC, Khalil H, Parker D. Chapter 11:

358 scoping reviews. In: Aromataris E, Munn Z, editors. Joanna Briggs institute Reviewer's 
medRxiv preprint doi: https://doi.org/10.1101/2020.10.15.20213249; this version posted October 16, 2020. The copyright holder for this preprint (which was not certified by peer review) is the author/funder, who has granted medRxiv a license to display the preprint in perpetuity.

It is made available under a CC-BY-NC-ND 4.0 International license .

359

360

361

362

manual: The Joanna Briggs Institute 2017 [Available from:

https://reviewersmanual.joannabriggs.org/.

19. Law M, Stewart D, Pollock N, Letts L, Bosch J. Westmorland M. Critical Review

Form-Quantitative Studies. McMaster University; 1998.

20. Tyndall J. AACODS Checklist: Flinders University; 2010 [cited 202002 August].

Available from:

https://dspace.flinders.edu.au/xmlui/bitstream/handle/2328/3326/AACODS_Checklist.pdf;jse

$\underline{\text { ssionid }=\mathrm{AB} 42 \mathrm{D} 4 \mathrm{~A} 4 \mathrm{AEAC} 2295306 \mathrm{ACA} 74417510 \mathrm{AA} \text { ?sequence }=4}$

https://dspace.flinders.edu.au/jspui/bitstream/2328/3326/4/AACODS Checklist.pdf,.

21. Braun V, Clarke V. Using thematic analysis in psychology. Qualitative research in psychology. 2006;3(2):77-101.

22. Ogolodom M, Mbaba A, Alazigha N, Erondu O, Egbe N, Golden I, et al. Knowledge, Attitudes and Fears of HealthCare Workers towards the Corona Virus Disease (COVID-19) Pandemic in South-South, Nigeria. Health Sci J. 2020.

23. UNICEF. Guinea-Bissau: COVID-19 Situation Report - \#17: UNICEF; 2020

[Available from: https://reliefweb.int/report/guinea-bissau/unicef-guinea-bissau-covid-19situation-report-17-25-31-july-2020.

24. Shaban ARA. Ghana coronavirus: 29,672 cases; 100-bed specialist hospital ready: Africanews; 2020 [cited 2020 August 21]. Available from:

https://www.africanews.com/2020/07/23/ghana-coronavirus-operational-guidelines-forchurches-mosques-issued/.

25. African Press Agency. Ghana: Press highlights recovery of 1870 health workers from Covid-19, others 2020 [cited 2020 August 22]. Available from:

http://apanews.net/en/news/ghana-press-highlights-recovery-of-1870-health-workers-fromcovid-19-others. 
medRxiv preprint doi: https://doi.org/10.1101/2020.10.15.20213249; this version posted October 16, 2020. The copyright holder for this preprint (which was not certified by peer review) is the author/funder, who has granted medRxiv a license to display the preprint in perpetuity.

It is made available under a CC-BY-NC-ND 4.0 International license .

26. Karmo H. Liberia: Minister of Health Attributes COVID-19 Infections Among Health Workers to 'State of Denial' of Nurses 2020 [Available from:

https://allafrica.com/stories/202007090657.html.

27. Tih F. Nigeria: 800 health workers infected with COVID-19: Anadolu Agency; 2020

[cited 2020 August 21]. Available from: https://www.aa.com.tr/en/africa/nigeria-800-healthworkers-infected-with-covid-19/1863747.

28. Clottey P, Dauda M. Striking Doctors in Nigeria Demand COVID-19 PPE, Hazard

Pay 2020 [cited 2020 August 24]. Available from: https://www.voanews.com/covid-19-

pandemic/striking-doctors-nigeria-demand-covid-19-ppe-hazard-pay.

29. Anmesty International. Nigeria: Authorities must protect health workers on the frontline of COVID-19 response 2020 [cited 2020 August 26]. Available from:

https://www.amnesty.ca/news/nigeria-authorities-must-protect-health-workers-frontlinecovid-19-response.

30. WHO. COVID-19 WHO African Region External Situation Report 23. WHO; 2020.

31. Brown W. Hospitals in tiny Guinea-Bissau 'overwhelmed' by the pandemic [News Article]. The Telegraph: Telegraph Media Group Limited; 2020 [Available from:

https://www.telegraph.co.uk/global-health/science-and-disease/hospitals-tiny-guinea-bissauoverwhelmed-pandemicl.

32. WHO. COVID-19 WHO African Region External Situation Report 15. Geneva: WHO; 2020.

33. Mwai P, Giles C. Coronavirus: How vulnerable are health workers in Nigeria? 2020 [cited 2020 August 25]. Available from: https://www.bbc.com/news/world-africa-53013413. 34. Nakri E. Striving to keep health worker infections at bay Geneva: WHO 2020 [cited 2020 August 26]. Available from: https://www.afro.who.int/news/striving-keep-healthworker-infections-bay. 
medRxiv preprint doi: https://doi.org/10.1101/2020.10.15.20213249; this version posted October 16, 2020. The copyright holder for this preprint (which was not certified by peer review) is the author/funder, who has granted medRxiv a license to display the preprint in perpetuity.

It is made available under a CC-BY-NC-ND 4.0 International license .

35. Nwosu-Igbo N. In the frontline of Nigeria's struggle with COVID-19 UNICEF; 2020.

36. Kursumovic E, Lennane S, Cook T. Deaths in healthcare workers due to COVID $\square$ 19: the need for robust data and analysis. Anaesthesia. 2020.

37. Temsah M-H, Al-Sohime F, Alamro N, Al-Eyadhy A, Al-Hasan K, Jamal A, et al. The psychological impact of COVID-19 pandemic on health care workers in a MERS-CoV endemic country. Journal of Infection Public Health. 2020.

38. Wasim T, Raana G, Bushra N, Riaz A. Effect of COVID-19 Pandemic on Mental Wellbeing of Healthcare Workers in Tertiary Care Hospital Annals of King Edward Medical University. 2020;26(2020):140-44.

39. Agren D. Understanding Mexican health worker COVID-19 deaths. The Lancet. 2020;396(10254):807.

40. WHO. WHO calls for healthy, safe and decent working conditions for all health workers, amidst COVID-19 pandemic Geneva, Switzerland: WHO; 2020 [Available from: https://www.who.int/news-room/detail/28-04-2020-who-calls-for-healthy-safe-and-decentworking-conditions-for-all-health-workers-amidst-covid-19-pandemic.

41. WHO. WHO donates Personal Protective Equipment (PPEs) to the Ministry of Health 2020 [Available from: https://www.afro.who.int/news/who-donates-personal-protectiveequipment-ppes-ministry-health.

42. Aguwa EN, Arinze-Onyia SU, Ndu A. Use of personal protective equipment among health workers in a tertiary health institution, South East Nigeria: Pre-Ebola Period. International Journal of Health Sciences Research. 2016;6(8):12-8. 43. Schwikowski M. COVID-19: Africa's health workers at risk 2020 [cited 2020 September 28]. Available from: https://www.dw.com/en/covid-19-africas-health-workers-at$\underline{\text { risk/a-53352778. }}$. 
medRxiv preprint doi: https://doi.org/10.1101/2020.10.15.20213249; this version posted October 16, 2020. The copyright holder for this preprint (which was not certified by peer review) is the author/funder, who has granted medRxiv a license to display the preprint in perpetuity. It is made available under a CC-BY-NC-ND 4.0 International license.

433 44. WHO. Shortage of personal protective equipment endangering health workers

434 worldwide 2020 [Available from: Shortage of personal protective equipment endangering

435 health workers worldwide.

436 45. OECD. Africa's Response to COVID-19: What roles for trade, manufacturing and 437 intellectual property? : OECD; 2020. 


\section{PRISMA 2009 Checklist}

\begin{tabular}{|c|c|c|c|}
\hline Section/topic & $\#$ & Checklist item & $\begin{array}{l}\text { Reported } \\
\text { on page : }\end{array}$ \\
\hline \multicolumn{4}{|l|}{ TITLE } \\
\hline Title & 1 & Identify the report as a systematic review, meta-analysis, or both. & 1 \\
\hline \multicolumn{4}{|l|}{ ABSTRACT } \\
\hline Structured summary & 2 & $\begin{array}{l}\text { Provide a structured summary including, as applicable: background; objectives; data sources; study eligibility criteria, } \\
\text { participants, and interventions; study appraisal and synthesis methods; results; limitations; conclusions and } \\
\text { implications of key findings; systematic review registration number. }\end{array}$ & 2 \\
\hline \multicolumn{3}{|l|}{ INTRODUCTION } & \\
\hline Rationale & 3 & Describe the rationale for the review in the context of what is already known. & $3-4$ \\
\hline Objectives & 4 & $\begin{array}{l}\text { Provide an explicit statement of questions being addressed with reference to participants, interventions, comparisons, } \\
\text { outcomes, and study design (PICOS). }\end{array}$ & 4 \\
\hline \multicolumn{4}{|l|}{ METHODS } \\
\hline Protocol and registration & 5 & $\begin{array}{l}\text { Indicate if a review protocol exists, if and where it can be accessed (e.g., Web address), and, if available, provide } \\
\text { registration information including registration number. }\end{array}$ & 2 \\
\hline Eligibility criteria & 6 & $\begin{array}{l}\text { Specify study characteristics (e.g., PICOS, length of follow-up) and report characteristics (e.g., years considered, } \\
\text { language, publication status) used as criteria for eligibility, giving rationale. }\end{array}$ & $5-6$ \\
\hline Information sources & 7 & $\begin{array}{l}\text { Describe all information sources (e.g., databases with dates of coverage, contact with study authors to identify } \\
\text { additional studies) in the search and date last searched. }\end{array}$ & 5 \\
\hline Search & 8 & $\begin{array}{l}\text { Present full electronic search strategy for at least one database, including any limits used, such that it could be } \\
\text { repeated. }\end{array}$ & S2 \\
\hline Study selection & 9 & $\begin{array}{l}\text { State the process for selecting studies (i.e., screening, eligibility, included in systematic review, and, if applicable, } \\
\text { included in the meta-analysis). }\end{array}$ & 7 \\
\hline Data collection process & 10 & $\begin{array}{l}\text { Describe method of data extraction from reports (e.g., piloted forms, independently, in duplicate) and any processes } \\
\text { for obtaining and confirming data from investigators. }\end{array}$ & 8 \\
\hline Data items & 11 & $\begin{array}{l}\text { List and define all variables for which data were sought (e.g., PICOS, funding sources) and any assumptions and } \\
\text { simplifications made. }\end{array}$ & 8 \\
\hline $\begin{array}{l}\text { Risk of bias in individual } \\
\text { studies }\end{array}$ & 12 & $\begin{array}{l}\text { Describe methods used for assessing risk of bias of individual studies (including specification of whether this was } \\
\text { done at the study or outcome level), and how this information is to be used in any data synthesis. }\end{array}$ & $\mathrm{n} / \mathrm{a}$ \\
\hline Summary measures & 13 & State the principal summary measures (e.g., risk ratio, difference in means). & 8 \\
\hline Synthesis of results & 14 & $\begin{array}{l}\text { Describe the methods of handling data and combining results of studies, if done, including measures of consistency } \\
\left(e . g ., I^{2}\right) \text { for each meta-analysis. }\end{array}$ & $\mathrm{n} / \mathrm{a}$ \\
\hline
\end{tabular}




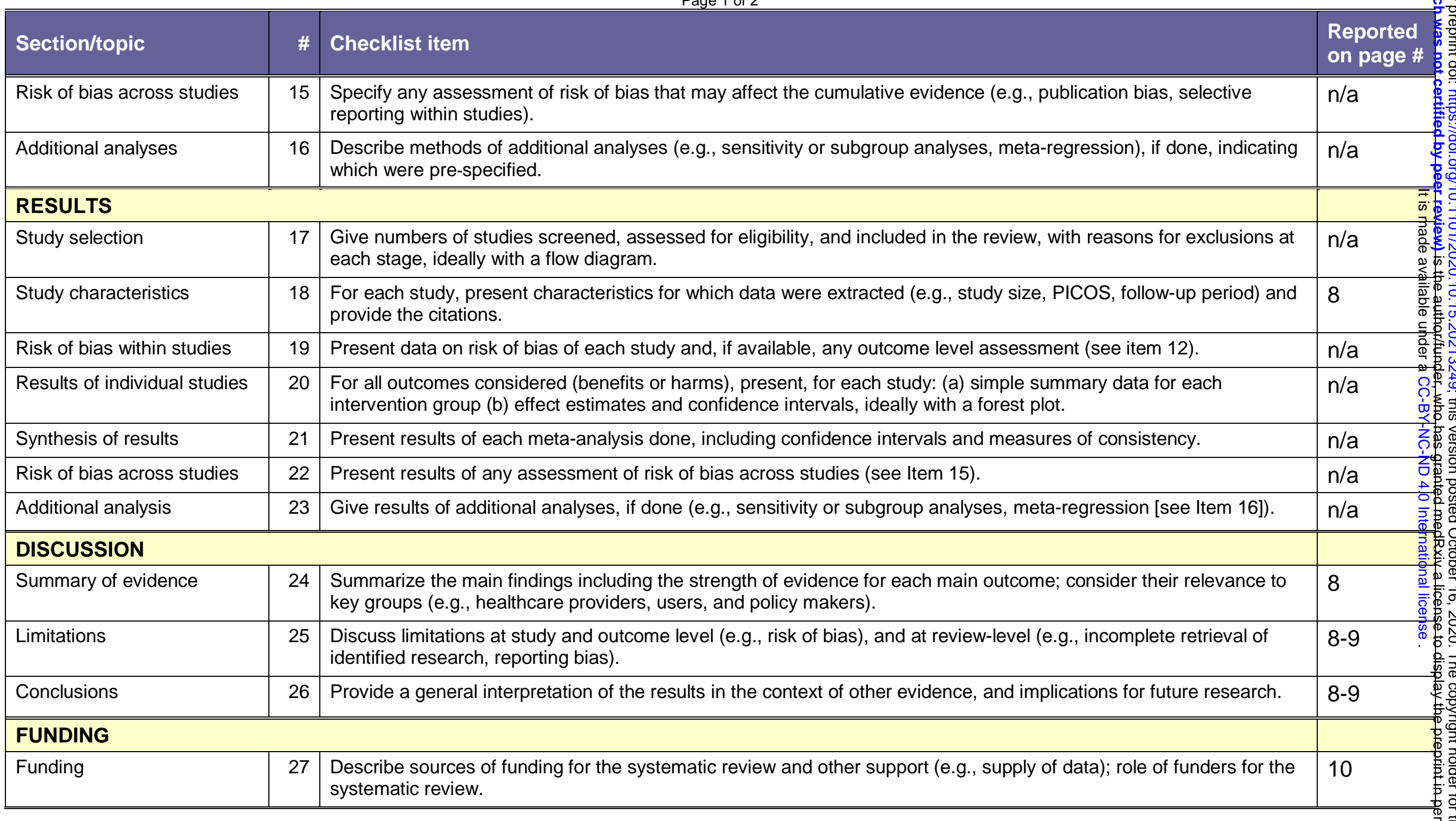

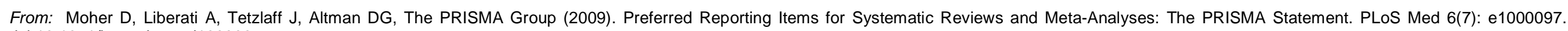
doi:10.1371/journal.pmed1000097 